\title{
'Extra costs' force UK to terminate bid to privatize astronomy facilities
}

London. The UK Department of Trade and Industry is abandoning its current efforts to find private managers for British telescopes in the Canary Islands and Hawaii, as well as for the Royal Greenwich Observatory and the Royal Observatory of Edinburgh. The decision represents an embarrassing setback to efforts to 'privatize' as much government sponsored research as possible.

A statement issued late last Friday (30 November) by Ian Taylor, the minister responsible for science, said that a decision had been made to terminate the tendering process for management contracts for these facilities, which are operated by the Particle Physics and Astronomy Research Council (PPARC). This was because "difficulties which have significant financial and legal implications remain to be resolved".

Although officials refuse to give further details of these difficulties, it is generally accepted that they focus on the costs of 'pensions crystallization' - the fact that any private contractor taking on the contracts will expect a substantial lump sum payment from the government to cover pension commitments (see Nature 384, 201; 1996).

The decision to suspend the tendering process, for which several potential bidders were lined up, came three days after the announcement of next year's science budget (see below) in which the Treasury does not appear to have made any extra money available to cover the costs to the research councils of preparing their institutes for possible transfer to private management.

It also coincides with a critical report from the House of Commons Select Com- mittee on Science and Technology, which has been holding hearings into the so-called 'Prior Options' exercise. This is the most recent of three government reviews aimed at identifying laboratories and research council institutes for privatization.

In its report, published on Monday, the committee says it does not question the

\section{IMAGE UNAVAILABLE FOR COPYRIGHT REASONS}

In the dark: the Infrared Telescope in Hawaii is one whose future management is unclear.

wisdom of seeking to achieve the maximum return on public investment. But it adds: "We are not convinced that the current reviews have been driven by concern for science, rather than financial considerations."

The committee says that the scale and conduct of reviews of research council institutes seen as possible candidates for privatization has been "profoundly unsatisfactory", adding that any possible benefits for these institutes "have almost certainly been overshadowed by the disruption caused".

The government's case has not been helped by its experience of trying to find a private manager for its astronomy facilities.

\section{British science to stay in steady state}

London. The British government announced last week that next year's science budget will be at the same level as this year, namely at $£ 1.3$ billion (US $\$ 2.1$ billion).

This figure is in line with plans for research published in July in the government's so-called Forward Look. But it means that, in real terms, funding for science will fall by about 2.5 per cent, the expected level of inflation. And the outlook for future years, according to these plans, looks even bleaker.

Nevertheless, given the general pressure on the government to cut public spending in what will be the last budget before the next general election, expected next spring, the general reac- tion has been pragmatic. "This might have been worse," says John Mulvey, secretary of the pressure group Save British Science. He says that the budget settlement reflects vigorous efforts by the Department of Trade and Industry's Office of Science and Technology to ward off deeper cuts.

There is also some relief for university researchers in the government's decision to provide an extra $£ 100$ million for recurrent spending by universities. This is being widely seen as an implicit acknowledgement by the government that it made a serious mistake last year when it cut $£ 450$ million from the universities' capital equipment budget over three years.

D. D.
Many astronomers would welcome a management structure independent of PPARC.

But there is widespread concern that the substantial legal costs already incurred, said to amount to about $£ 2$ million, have had to come out of the research council's operating funds. The pain to astronomers has been increased by the fact that PPARC is already heavily strapped for funds.

"We are extremely angry," says Phil Charles, head of the department of astrophysics at the University of Oxford, and a member of one of several panels set up to prepare for the tendering process. "We should have said that we would only take on the work of these panels once we had received a guarantee that these costs would be covered from elsewhere."

PPARC's embarrassment has been seized on by Adam Ingram, the opposition Labour Party's shadow minister for science and technology. Ingram said on Monday that the decision shows that the government was "clearly in disarray" over the prior options review policy.

Ingram claims that the government's apparent U-turn underlines his own party's position, namely that "there are no advantages to the science and research base of this country in the privatization of our worldrenowned national institutions such as the Royal Observatories and other research institutions". Ingram says that if - as now seems highly likely — Labour is elected to power next year, it will make its own assessment of the need for management changes "based on science, not ideology".

The government itself remains committed, at least in principle, to continuing along the path it has laid out. Taylor's statement said that tendering for the management contracts "will proceed once the difficulties have been resolved and the costs and benefits reassessed".

But the government still faces the thorny question of how to meet the pension commitments of many other research institutes which, in principle, it would like to see privatized. There is a widespread feeling that, as with the observatories, crucial decisions on at least some of these may now be postponed until after the general election.

The select committee made clear its support for a more cautious approach. "At a time when research councils can fund far fewer than 50 per cent of the alpha-rated proposals they receive, costly reorganization should not be undertaken without a balance of evidence in its favour," says the committee's report.

David Dickson 